\title{
Adverse Event associated with Hospitalization
}

National Cancer Institute

\section{Source}

National Cancer Institute. Adverse Event associated with Hospitalization. NCI Thesaurus.

Code C83052.

An indication or description that an adverse event is associated with or prolongs

hospitalization. 